\title{
COST IMPLICATIONS OF THE ISO 9001 QUALITY MANAGEMENT SYSTEM IN SOUTH AFRICAN MANUFACTURING ORGANISATIONS
}

\author{
K.R. Ramdass ${ }^{1 *}$ \& F. Nemavhola ${ }^{1}$
}

\section{ARTICLE INFO}

\section{Article details}

Submitted by authors 28 Feb 2018

Accepted for publication 22 Jun 2018

Available online $\quad 31$ Aug 2018

\section{Contact details}

ramdakr@unisa.ac.za

\section{Author affiliations}

1 Department of Mechanical and Industrial Engineering, University of South Africa

DOI

http://dx.doi.org/10.7166/29-2-1741
ABSTRACT

Many organisations throughout the world are aggressively adopting the ISO 9001 international quality standard. It heightens improved productivity and efficiency at an operational level. However, the astronomical costs of implementation decrease the benefits in cost savings, leaving executives disgruntled. This study seeks to explore the significance and impact of related variables in implementing the international quality system standard ISO 9001 in South African organisations. The study aims to highlight that, although there are cost implications relating to the prevention, appraisal, and failure costs of product quality, organisations become internationally competitive through the effective maintenance of the ISO quality management systems. The investigation was conducted through a qualitative exploratory research methodology involving unstructured interviews using open-ended and closed-ended questions. A total of 50 organisations from different manufacturing sectors were identified to participate in the study through nonprobability snowball sampling. Five manufacturing organisations were identified to start off the snowball methodology. Questionnaires were distributed to these organisations to determine what motivated organisations to implement ISO 9000 systems. The study highlighted that the implementation of ISO standards was fundamental to customers' requirements of all industries, while well-maintained systems can reduce quality costs and improve organisational effectiveness.

\section{OPSOMMING}

Oor die afgelope jare is die ISO 9001 standaard wêreldwyd aggressief deur baie organisasies aangeneem. Dit bied geleenthede vir voortdurende verbetering en doeltreffendheid op 'n operasionele vlak. Die inwerkingstellingskoste is egter buitensporig en verminder die voordele van kostebesparing, wat uitvoerende beamptes ontevrede laat. Hierdie studie poog om die belangrikheid en uitwerking van die inwerkingstelling van die Internasionale Gehaltestandaard ISO 9001 op die verlaging in gehaltekoste in SuidAfrikaanse vervaardigingsbedrywe te verken. Baie Suid-Afrikaanse maatskappye het by hierdie globale neiging aangesluit in 'n poging om globaal mededingend te bly. In die laaste tyd word ISO 9001 sertifisering nie meer hoog geag deur organisasies nie, aangesien die meeste begin het om die invloed van hoë koste te ervaar. Die studie poog om finansiële winste te beklemtoon wat deur middel van die inwerkingstelling van die ISO 9001-standaarde behaal kan word. Dit word bereik deur middel van ' $n$ kwalitatief-verkennende navorsingsmetode wat ongestruktureerde onderhoude insluit en vereis dat ope en geslote vrae op 'n Likert-skaal beantwoord word. Altesame 50 organisasies was gewillig om aan die studie deel te neem. 
The quality management paradigm has seen drastic measures in the business world. There are two predominant reasons for this uptake: the need to satisfy the customer, and meeting the requirements of the supply chain. In fulfilling these requirements, industry is required to buy into these standards. There is mounting evidence that such adoption of standards enables the effective evaluation of the value stream through the elimination of all non-value added activities through process management, thereby enabling process optimisation. However, the costs of implementation are exorbitant, and reduce the benefits in cost savings, leaving executives disgruntled.

This study seeks to explore the significance and impact of implementing the international quality system standard ISO 9001 on the reduction of quality costs in South African manufacturing industries. Many South African companies joined in this global trend in an effort to remain globally competitive. Lately, however, many organisations have no longer held certification to this standard in high regard, as most have started to feel the effect of the high implementation and maintenance costs. The study aims to highlight the financial gains to be made through the implementation of the ISO 9001 standards. This is achieved through a qualitative exploratory research method involving unstructured interviews using open-ended and closed-ended questions. Fifty organisations participated in the study, which targeted supervisors, managers, and quality personnel. It is important to note that qualitative and quantitative analyses were done in different organisations.

\section{LITERATURE REVIEW}

It needs to be stressed that ISO 9000 does not fulfil an objective or attain a predetermined result; rather, it provides a platform for ensuring that products and services are attained through a formalised set of processes and procedures. Gryna [1] points out that the ISO 9000 series should be viewed as identifying the minimum elements of a quality system. He adds that the emphasis in ISO 9001 is not on results but on the existence of conformity to the elements of a quality system. He suggests the complementary use of the Malcolm Baldridge National Quality Award criteria if a company wishes to move into world-class manufacturing where tangible results can be experienced.

Foster [2] agrees with this perspective, concluding that ISO 9001 is useful for organisations with a compelling marketing reason for seeking registration. If an organisation's largest customer requires registration, ISO 9001 can be regarded as a cost of doing business with such a customer. He concedes that, when ISO 9001 is used correctly, it can improve systems; however, this does not necessarily mean that quality is improved.

Allen, Moon, Naveh, and Marcusal [3] mention that many of the companies that currently have the certification have obtained it for only one reason: their customers required it. He points out that, although this is a valid reason, it should not under any circumstances be the only one, as there is a danger associated with this kind of thinking. The danger is that, although customer focus is one of the key aspects of the ISO 9000 system, many other principles, such as people involvement, leadership, a process approach, a systematic approach to management, a factual approach to decision-making, continual improvement, and mutually beneficial supplier relationships are equally important. The system is built on these eight principles; focusing only on one will not provide the full benefits of the system. These key principles provide a holistic synergy that enables the effective operationalisation of the organisation.

By contrast, Castka and Balzarova [4] bluntly states that ISO 9001 is ineffective. In a column entitled "ISO 9001: More hindrance than help", he describes his regret at championing ISO 9001 in his company, as he found that it was just an added expense, an extra overhead to the company, without any real benefits.

In a study carried out by Heras et al [5], the contention that ISO 9001 registration improves performance was refuted because it was seen as a cause-and-effect relationship. The study acknowledged, however, that a well-managed and maintained system outperforms non-ISO 9001 registered companies. 
This study posits the use of both qualitative and quantitative research methodology, using an exploratory research design to collect data. The results in exploratory research provide insight into some of the reasons why certain relationships occur. A case study analogy was used to solicit information through informal discussions, while a questionnaire was developed to ascertain the reasons that motivated organisations to implement ISO 9000 systems. The questionnaire design consisted of open- and close-ended questions. Even though the interviews were largely unstructured, a questionnaire was sent to the interviewees a week in advance so that they could familiarise themselves with the general aspects covered during the actual interviews, enabling them to prepare appropriately. Also, the questionnaire was simply to suggest the general theme for discussion, and further questions were posed during the spontaneous development of the interaction. The motivations for the one-to-one interview with the respondents were the following:

a) The respondents were likely to take the questions more seriously in the presence of the researcher, and hence give more valid answers.

b) The respondents could clarify their answers and give more details verbally than if they were just responding in writing.

c) Sensitive and emotional questions require face-to-face interaction that cannot be done through telephonic and postal surveys.

This study was limited to manufacturing organisations within Gauteng and surrounding areas within $300 \mathrm{~km}$ of Gauteng. The reason for this limitation is that the research was conducted through oneto-one in-depth unstructured interviews with the quality manager, co-ordinators, and quality champions (the middle management people in the organisations who deal directly with issues of quality management); hence the constraint on the travelling distance for the researcher, taking into account the costs of travelling and the time constraints. Higher and lower levels were excluded from the research. The motivations for this are as follows:

a) The departmental middle manager is low enough in the management structure to have handson experience of running the ISO system, but high enough to have intimate knowledge of the financial details relating to the costs of running the system, and its impact on the costs of poor quality.

b) A person at this level in the organisation understands the terminology used in this research, and in quality management as a whole.

c) The researcher was at this level of management; and once respondents knew this, they were more likely to give truthful and detailed answers, as they would feel that the interviewer understood all the concepts and problems.

The layout of the questionnaire assisted in the development of a conceptual framework to determine the relationship between variables, and helped to determine the research design and data collection method. Decisive conclusions are made with caution, depending on the relationship between variables. There is a reliance on secondary research and informal discussions in the development of conclusions [6]. Diagram 1 shows the path diagram of the methodology and design.

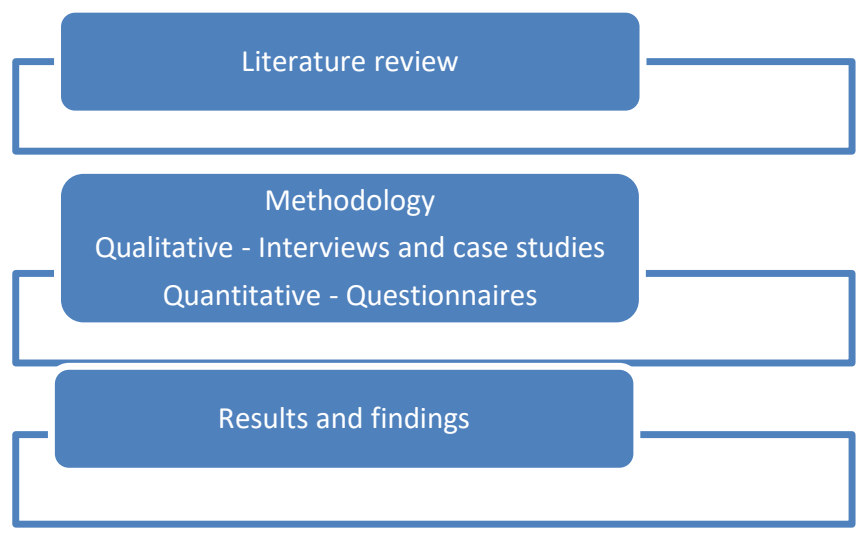

Diagram 1: Path diagram of the methodology and design 


\subsection{Motivation for the study}

This section provides an analysis of two case studies related to waste and costs in the textile and clothing industries respectively. It shows that, without proper systems in place, industries continue to waste millions in their use of resources. The motivation for this section is that every aspect in an organisation is measurable and controllable. The ISO 9000 system provides a fundamental platform for measurement and analysis of root-cause analysis and the elimination of non-value.

A case study analysis was performed on these two organisations - one from the textile industry, and one from the clothing industry - regarding quality costs. It is important to note the financial gains for reducing defective products and waste. The analysis done at a textile facility reveals the following waste records:

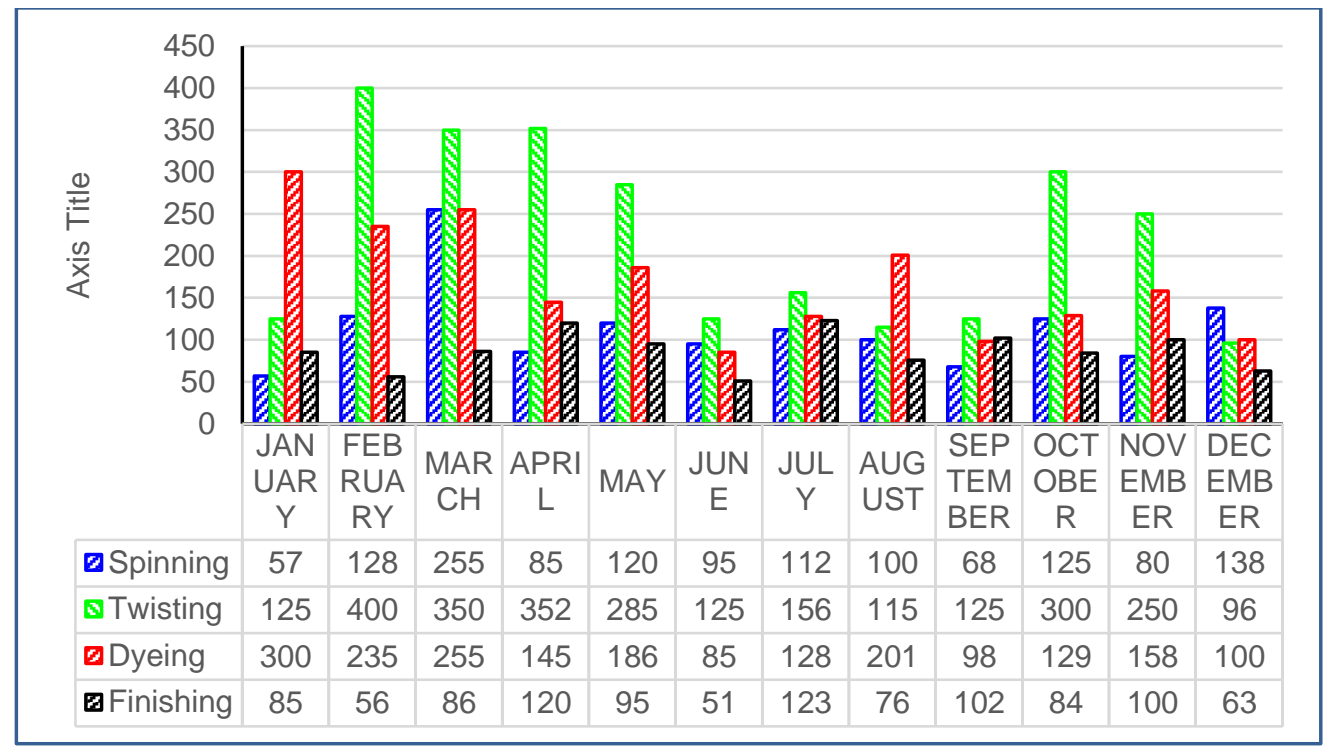

Figure 1: Breakdown of waste and costs per department due to ISO implementation (see online version for colour)

A disturbing issue that was observed was that a person was specifically hired to cut up waste without investigating the reasons for such waste. With reference to Figure 1, the approximate waste per annum for the organisation was 7000 kilograms. This happened for more than ten years. The money that was wasted in this way was exorbitant. The figure shows that most of the waste was generated in the twisting department. The industrial engineering methodology of root-cause analysis was performed in the twisting department, and highlighted the following issues:

- Inefficient operator patrol

- Cheese shape not parallel due to varying tensions

- $\quad$ Poor condition of machinery, and frequent repairs

- $\quad$ Differing dimensions of stainless steel springs

In the endeavour to reduce waste, the following action was taken from an industrial engineering perspective:

- $\quad$ Define the problem - generation of waste in each process of manufacturing

- Identify the causes of waste - input/process/output

- Identify the principal contributor of waste

- $\quad$ Develop a strategy to address and curtail waste creation

In order to address the problem, the operators, supervisor, manager, maintenance personnel, and human resources were engaged to seek an action plan for the way forward. $5 \mathrm{~S}$ principles were 
applied to re-organise and re-engineer the workplace. The maintenance team evaluated all relevant machinery in order to replace damaged components and service all machinery. A schedule was then formulated to address all machine-related issues. Human Resources trained the operators in production quality, while the Work-Study department provided standard operating procedures for all operations. Regular tests were conducted by the quality department by sampling the production, and immediate action was taken to prevent the production of waste. Regular management meetings about factory performance were held with the executive management after inception of the improvement controls $[7,8]$.

The implementation of the ISO 9000 system at a textile facility (represented in Figure 1) yielded a 30 per cent reduction in waste over a year. Over a five-year period, waste related to the use of all resources was reduced by 80 per cent, while material and labour efficiency improved by 30 per cent, and productivity improved by 35 per cent.

Table 1: An analysis in the clothing industry indicated the following

\begin{tabular}{|l|l|l|}
\hline Department & Percentage Waste & Cost implications \\
\hline Incoming raw materials - damaged fabric & $2 \%$ of purchased materials (100 metres) & 2 metre (R200) R400 \\
\hline Cutting room & $16 \%(100) \times$ R200 & R3200 \\
\hline Machining (repairs/rework+labour) & $7 \%$ & R5000 \\
\hline Finished goods & $3 \%$ & R2500 \\
\hline & & \\
\hline
\end{tabular}

The estimated waste per day in the clothing industry costs R11 100; but that can be reduced by 50 per cent through a system of quality management.

A team was formed to deal with waste in its various forms, especially the following:

1. Operator training and retraining - engagement with the training department

2. Machine maintenance - engagement with operators and maintenance department

3. Evaluation of quality of all materials - quality department and suppliers

The effective monitoring and evaluation of ISO 9000 standards would not only improve the tangible and intangible aspects, but would also create an enabling environment in which product and service quality would continuously improve. Although some organisations were opposed to the system due to its labour intensive nature, others experienced its benefits.

\subsection{Analysis of the questionnaire}

This section analyses the motivation to seek ISO 9000 registration, using core variables of the ISO 9000 quality management system. It also provides a qualitative analysis of informal discussions to supplement the objective of the study.

The top five reasons for an organisational motivation to seek ISO 9000 registration were regarded as the independent variables [5, 9-12]. The top five benefits realised since the implementation of ISO 9000 were regarded as the dependent variables [13-18]. The correlations between the independent and dependent variables were computed [18].

The independent variables were:

i) quality improvement benefits

ii) customer demand

iii) pressure from competitors

iv) marketing strategy

v) part of a larger strategy

These five independent variables, as the quality champions perceived them, were correlated with the five observed variables (treated as dependent variables for this study). 
The dependent variables were:

i) fewer defective items

ii) reduced quality costs

iii) improved product reliability

iv) increased market share

v) improved corporate reputation

The five independent and five dependent variables were used to construct the closed-ended questions in the questionnaire used as the survey instrument. This was done in two parts. Part 1 solicited information from the quality personnel by asking them to rank from 1 to 5 (where 5 equals 'most important' and 1 equals 'least important') the reasons that motivated their company to implement ISO 9000 registration. Part 2 solicited information by asking them to select from 1 to 5 the organisation's degree of success in achieving benefits since the registration.

Both the literature and empirical evidence indicate that some organisations implement standards for the sake of certification, while others engage the standards to improve the organisation. Despite the effort put into implementing the standards, organisations perform reasonably poorly during the 'audit function'.

The data obtained for the first section of the study is explained and illustrated below.

Content analysis was carried out to determine the impact and weaknesses of the ISO 9000 standard as perceived and experienced by South African manufacturing organisations. The ten most important keywords (themes) that highlight the interviewees' opinions are:
i) increase in paperwork
ii) bureaucratic
iii) practical
iv) lacks 'how to'
v) little impact
vi) marketing tool
vii) inadequate
viii) knowledge sharing
ix) defects not reduced
x) systems management

The frequency of each keyword per interview was tallied, after which the totals across all 50 interviews were added. The results are shown in Figure 2.

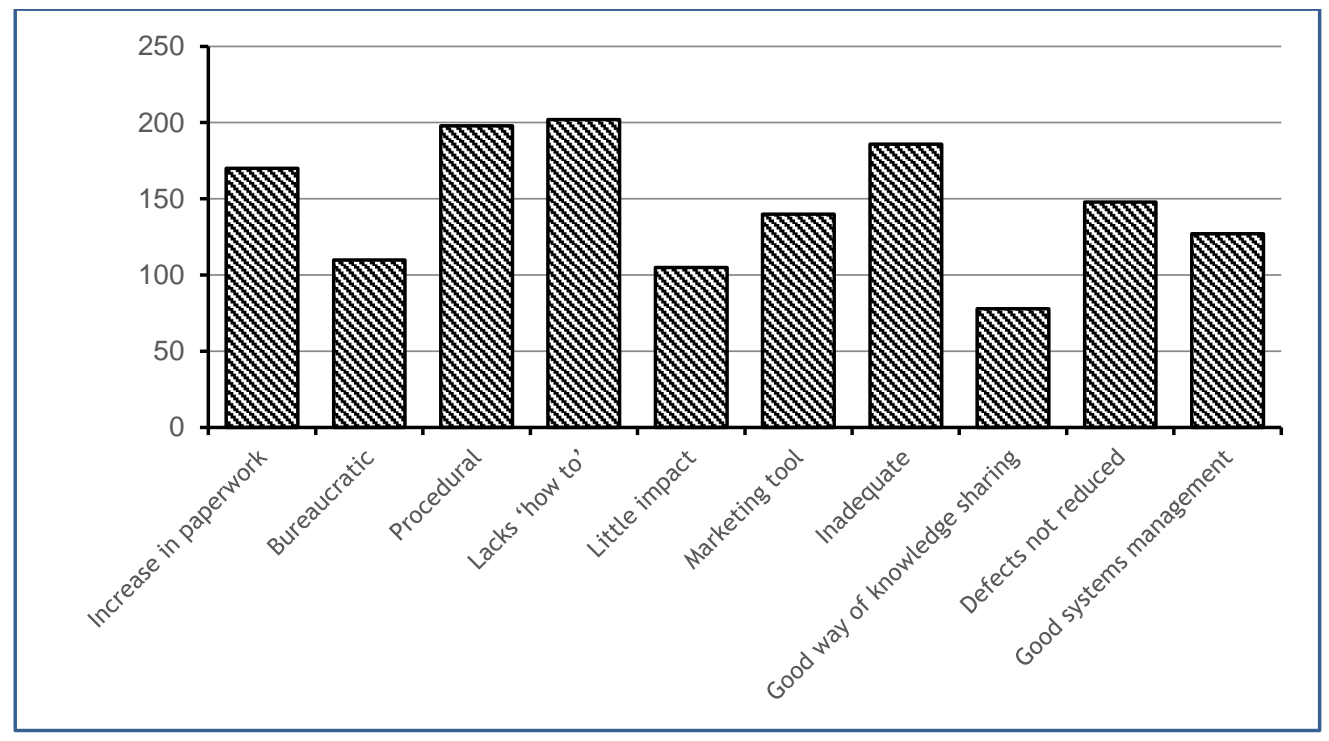

Figure 2: Content analysis for answers to open-ended questions (frequency analysis) 
In the second section of the questionnaire, the scores for the motivating factors were added across the 50 organisations. Then the ranking of each motivating factor was determined from the total score value and compared with the other motivating factors. The results for the motivating factors are summarised in Table 2.

Table 2: Motivating factors

\begin{tabular}{|l|l|l|}
\hline Motivating factor & Total score & Rank \\
\hline Customer demand & 228 & 1 \\
\hline Pressure from competitors & 170 & 2 \\
\hline Marketing strategy & 161 & 3 \\
\hline Quality improvement initiative & 131 & 4 \\
\hline Part of a larger strategy & 60 & 5 \\
\hline
\end{tabular}

In a similar way, the benefit scores were added across the 50 organisations. Then the overall ranking of each benefit was determined from the total score value and compared with the other benefits. The results are shown in Table 3.

Table 3: Benefit scores

\begin{tabular}{|l|c|l|}
\hline Motivating factor & Total score & Rank \\
\hline Increased market share & 243 & 1 \\
\hline Improved corporate reputation & 219 & 2 \\
\hline Fewer defective items & 198 & 3 \\
\hline Improved product reliability & 132 & 4 \\
\hline Reduced quality costs & 100 & 5 \\
\hline
\end{tabular}

The motivating factor rankings and benefit rankings provided the information for the key focus of this section of the study. Using Minitab software, Spearman's coefficient of rank correlation was calculated between each motivating factor and each benefit to test the strength of the relationship. This correlation coefficient was then taken as an indication whether motivating factors determined the benefits realised from implementing the ISO 9000 standard in South African manufacturing organisations (ranging from textile, tea, and printing, to automotive).

In summary, this would answer the following question: What relationships exist between the perceived benefits realised, and the motivation to seek ISO 9000 registration, in the South African context? The results of this correlation analysis are shown in Figure 4.

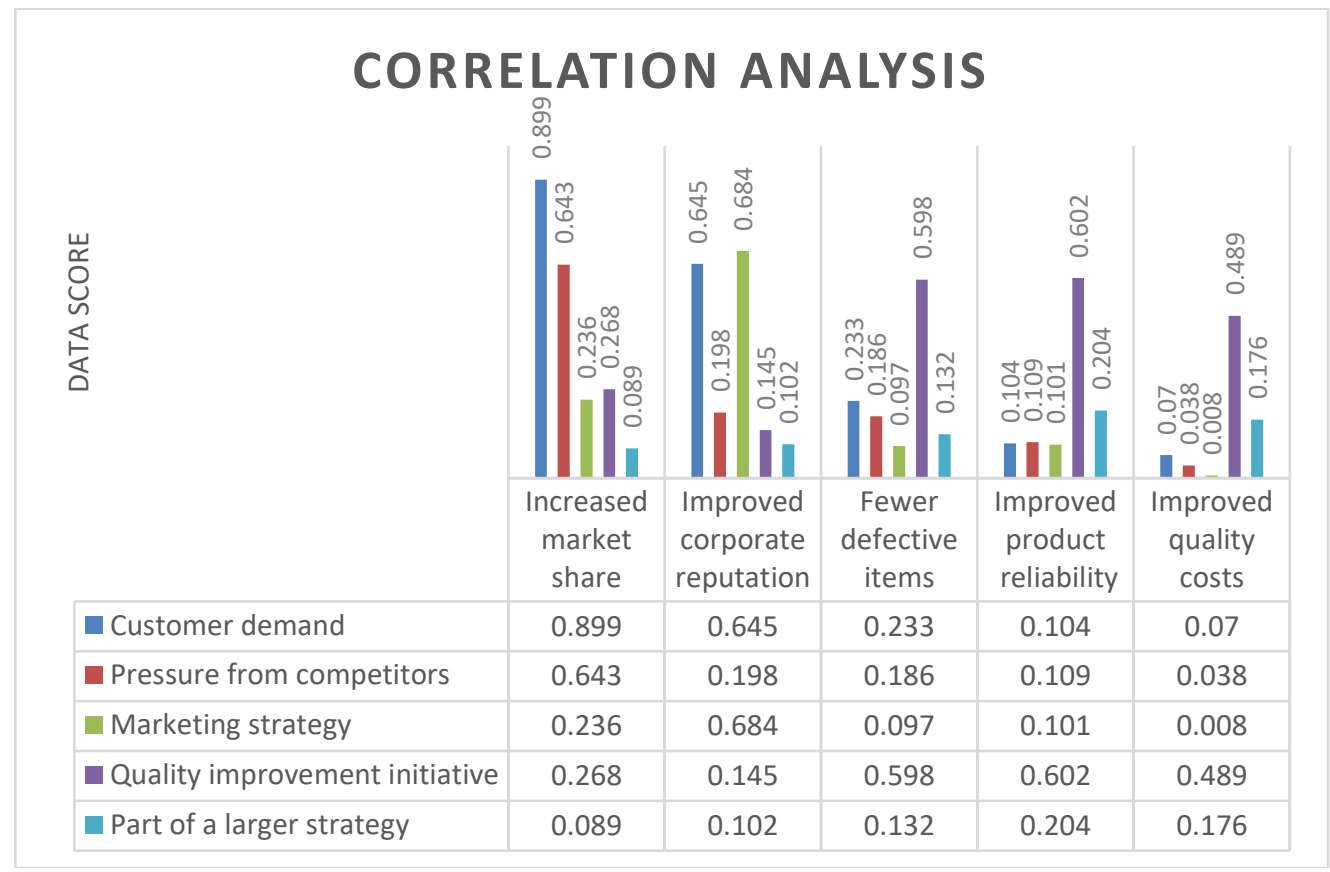

Figure 4: Summary of motivating factors vs benefits coefficient of rank correlation 
The data correlations between the two variables are shown in Figure 4. The main finding was that the registered companies had the same performance before and after registration. Even though registered organisations performed better than non-registered ones, they were already performing at an advanced level before their ISO 9001 registration. The study speculates that high-performing organisations tend to adopt the ISO 9001 standard at a higher rate than poor performing organisations, thus creating the illusion that ISO 9001 registration is associated with better performance [19-22].

\section{FINDINGS}

One of the fundamental flaws is the notion of registering for ISO 9000 quality management systems solely to meet customers' demands. Although this may provide a greater market share, the other principles of the system are ignored. This would definitely erode the benefits that could be achieved through a synergy of all eight principles. It is interesting to note that most of the South African manufacturing organisations used in this study cited customer demand as the main motivation for implementing the ISO 9000 standard; In fact, 73 per cent of the respondents ranked this motivating factor ' 5 ', the highest rank. Most of them stated that certification to ISO 9000 had become a requirement for doing business both locally and abroad. This applied to both prospective and current customers. Organisations found themselves with no other option than to get certification as quickly as possible if they wanted to sell their products.

This finding is in line with the results of most previous researchers elsewhere in the world, as well as with the opinions of critics of the ISO 9000 standard [1, 23-28]. Neely [29], for example, found that virtually all original equipment manufacturers (OEMs) in the United States required ISO certification of their manufacturing plants during the time that he conducted his research.

The results also indicated that 81 per cent of the respondents stated that the most important benefit of implementing the ISO 9000 was increased market share. This comes as no surprise, as most of these organisations had implemented the standard either to increase their market share (customer demand) or to maintain their market share (pressure from competitors) [30, 31].

Hence, as shown in Table 3, the highest-ranked benefit realised is increased market share, followed in second place by improved corporate reputation.

ISO 9000 was preceded by ISO 8402 in the year 2000. The continuous development and refinement by the International Standards Organisation enabled the introduction of ISO 9000:2015. The principles form the core pillars of the quality management system (QMS), and clearly state the synergistic nature of its operation. The evolution of ISO 9000 clearly reveals its significance for industry stakeholders. This can, of course, be easily explained by the fact that ISO 9000 was viewed as important - hence the requirement from customers that their suppliers be certified. So, once an organisation was certified, its reputation grew.

It is interesting to note that the lowest-ranked benefit realised and experienced by the organisations in the study was reduced quality costs. Most of them indicated that running the ISO 9000 standard was in itself a quality cost because of audits, appointing a quality management representative, and generally running the system. Thus any financial benefits through reduced quality costs were offset by the increased costs of running the standard itself $[1,13,32]$.

However, of the few companies (eight per cent) that identified a quality improvement initiative as the main motivation for seeking ISO 9000 certification, at least 50 per cent reported fewer defective items and product reliability as their primary benefits. This is in line with the opinion of other quality experts and researchers [13, 17, 22, 33, 34], that this is inevitable: once a company recognises that it can use the ISO 9000 standard to achieve quality improvement, it will reap such rewards.

The strongest relationship was found between the motivating factor of customer demand and the benefit of increased market share, with a correlation of 0.899 . This phenomenon has already been explained above. The weakest relationship was between the motivating factor of customer demand and improved quality costs; it can be said, in fact, that there was no relationship in this case.

However, two positive themes emerged quite strongly. One of these, with the second highest frequency at 198, was that the ISO 9000 standard greatly improved procedures and standardised, to 
an extent, the way of doing things. Also positive was the perception that the standard was a good systems management tool, especially with the principle of periodic audits to keep procedures in check. The frequency of this perception was quite significant at 127, meaning that it was mentioned at least twice in every interview.

\section{CONCLUSION}

The main motivation for undertaking this study has been that many organisations around the world no longer hold certification to the ISO 9000 standard in high regard, as most have begun to feel its cost implications. Companies worldwide have discovered that certification to this standard is no guarantee of product quality. Many have realised that, even though their suppliers might be ISO 9000 certified, they still receive defective material from them.

The study has examined the experiences of quality personnel of the ISO 9000 standard in South African manufacturing organisations. The study also aimed to find out whether the perceived failure of the standard to reap benefits for organisations was related to the main motivating factors for implementing it in the first place.

The study's results support the fact that customer pressure was the driving motive behind most companies pursuing certification. Most of the organisations ranked customer demand as the most important reason for implementing the ISO 9000 standard, while they gave the lowest score rating to improved quality costs/fewer defective items as benefits. The companies that ranked a quality improvement initiative as the main motivating factor argued that, when companies are forced to implement the ISO 9000 certification, management is unlikely to be fully committed to the process, and so certification is unlikely to produce the full benefits. However, one can still argue that ISO 9000 is ineffective in making companies implement and manage high performing quality systems. Companies either care about quality, and benefit from that approach, or they do not care about quality, and suffer as a result.

The results showed that the industry identified three main weaknesses of ISO 9000 certification:

i) It lacks the 'how to' approach to reducing poor quality

ii) It increases paperwork without necessarily improving product quality

iii) It is inadequate in improving quality, as it does not provide tools and methods - this it has little impact on reducing quality problems.

This study has contributed to the existing literature in that it adds the South African context to the literature; and the weaknesses of the standard have been obtained from organisations themselves, which has been another gap in the literature.

Those companies that have already implemented the standard, but that are unhappy with the types of benefits obtained, may need to change their way of thinking about the standard. They are encouraged to adopt other quality improvement practices and principles - for instance, TQM, Six Sigma, and World Class Manufacturing (WCM) - and to combine them with the ISO 9000 standard to realise the full benefits of quality improvement. Further research needs to be conducted to evaluate the functioning of the ISO 9000 standard in conjunction with WCM principles.

\section{MANAGERIAL IMPLICATIONS AND RECOMMENDATIONS}

Since the results show that there is a link between motivating factors and the type of benefit resulting from the implementation of the ISO 9000 standard, those organisations that have not yet implemented this standard, but that plan to do so, should review their reasons for doing so to avoid frustration.

And in order to maximise the benefits of implementing this standard, an organisation should approach the procedure using an organisational behavioural strategy to ensure the motivation required to engage the workforce. Soliciting employee engagement in an early stage of any process improvement mechanism is key to accountability and responsibility. 
Those companies that have already implemented the standard and are not happy with the type of benefits that they are getting may need to make a shift in their way of thinking as far as the standard is concerned. They are encouraged to adopt other quality improvement practices and principles, for example, TQM, Six Sigma, and World Class Manufacturing (WCM), and combine them with the ISO 9000 standard to realise the full benefits of quality improvement.

These organisations need not adopt the whole of Six Sigma or WCM, but could simply take the concepts from these methodologies that are missing in the ISO 9000 standard - for example, rootcause analysis and focused improvement $(\mathrm{FI})$. As the results from a study conducted by Arumugam et al. [34] show, ISO 9000 certification and TQM practices have a significant, positive relationship with each other. This finding supports the argument that the ISO 9000 standard can be used as a 'stepping mechanism' to total quality.

The ISO 9000 quality management system, if implemented with a focus on only one of the principles, will definitely be limited in its contribution to the organisation. With managerial insight and commitment, and a synergistic approach to the principles, the ISO 9000 system can move all operations towards continuous improvement. However, it needs to be well-managed and wellmaintained.

Some of the major managerial implications of adopting the ISO systems are the following:

- Management commitment, regardless of the benefits

- Continuous monitoring and evaluation of status

- $\quad$ Defining the purpose of the system

- Creating an enabling environment for long-term benefits

The organisation will require continuous training on quality matters, and the development of quality circles that enable communication across departments. Such communication enables swift action on deficiencies. The eight principles are a simplified theoretical framework that forms the foundational component of the ISO 9000 quality management system. Implementing all eight would enable the benefits of ISO 9000 to be intensified. These would be the following, as identified in this study:

- Management commitment and leadership: This is one of the most important elements for the successful implementation of ISO standards. Without such support, the system will not function effectively.

- Credibility and image: the ISO 9000 series of standards is internationally recognised as a basis for business transactions. It formulates a structured approach to continuous improvement through which communication between all levels of personnel is promoted.

- Customer satisfaction: The continuous drive to plan for and meet customer requirements is a key element. This encourages repeat customers and customer loyalty.

- $\quad$ Process integration: The process approach enables each variable to be scrutinised, thereby promoting continuous improvement and performance.

- $\quad$ Evidence-based decision-making: Decisions are factually orientated through the collection of statistical information that is evidence-based and improvement-related.

- Culture of continuous improvement: The standard adopts the input/process/output paradigm to enable and create a culture of quality that is improvement-oriented.

- The measurement of performance is enabled throughout the organisation, such that comparisons may be tabled year after year, thus improving the speed of return.

- Employee engagement: The systems and process approach enables communication among employees, who are then able to identify and resolve problems.

Finally, ISO 9000 implementation is a slow process that requires change in the culture of quality perceptions. The impact of implementation is gradual, and focuses on people and attitude change throughout the organisation. With diversity being a challenge in the South African context, management commitment to labour buy-in is paramount in order to achieve the desired outcomes of the ISO 9000 quality system. 


\section{REFERENCES}

[1] Gryna, F.M. 2001. Quality planning and analysis: From product development through use. McGraw-Hill Science Engineering. United States of America.

[2] Foster, S.T. 2001. Managing quality: An integrative approach. Upper Saddle River: Pretice Hall, United Kingdom

[3] Naveh, E. 1999. ISO 9000 survey '99: An analytical tool to assess the costs, benefits and savings of ISO 9000 registration. QSU Publishing Company. United Kingdom

[4] Castka, P. \& Balzarova, M.A. 2008. The impact of ISO 9000 and ISO 14000 on standardisation of social responsibility: An inside perspective, International Journal of Production Economics, 113, pp. 74-87.

[5] Heras, ,I. Dick, G.P. \& Casadesús, M. 2002. ISO 9000 registration's impact on sales and profitability: A longitudinal analysis of performance before and after accreditation, International Journal of Quality \& Reliability Management, 19, pp. 774-791.

[6] Cooper, D.R., Schindler, P.S. \& Sun, J. 2006. Business research methods, Vol. 9. New York: McGraw-Hill Irwin. United States of America

[7] Masithulela, F. \& Ramdass, K. 2015. Delivery challenges at a mechanical testing centre facility: A case study of a railway system in South Africa, South African Journal of Industrial Engineering, 26, pp. 216-230.

[8] Nemavhola, F. \& Ramdass, K. 2017. Using statistical process control and six sigma to critically analyse safety of helical springs: A railway case study, International Journal for Quality Research, 11 (3), pp. 627 642.

[9] Saraph, J.V., Benson, P.G. \& Schroeder, R.G. 1989. An instrument for measuring the critical factors of quality management, Decision Sciences, 20, pp. 810-829.

[10] Ferlie, E.B. \& Shortell, S.M. 2001. Improving the quality of health care in the United Kingdom and the United States: A framework for change, The Milbank Quarterly, 79, pp. 281-315.

[11] Dick, G.P., Heras, I. \& Casadesús, M. 2008. Shedding light on causation between ISO 9001 and improved business performance, International Journal of Operations \& Production Management, 28, pp. 687-708.

[12] Eisenhardt, K.M. 1989. Building theories from case study research, Academy of Management Review, 14, pp. 532-550.

[13] Feng, M., Terziovski, M. \& Samson, D. 2007. Relationship of ISO 9001: 2000 quality system certification with operational and business performance: A survey in Australia and New Zealand-based manufacturing and service companies, Journal of Manufacturing Technology Management, 19, pp. 22-37.

[14] Lee, T.Y. 1998. The development of ISO 9000 certification and the future of quality management: A survey of certified firms in Hong Kong, International Journal of Quality \& Reliability Management, 15, pp. 162177.

[15] Spector, B. \& Beer, M. 1994. Beyond TQM programmes, Journal of Organizational Change Management, 7, pp. 63-70.

[16] Fletcher, S. 1993. Quality and competence: Integrating competence and quality initiatives. Kogan Page Publishers. United Kingdom

[17] Gotzamani, K.D. \& Tsiotras, G.D. 2002. The true motives behind ISO 9000 certification: Their effect on the overall certification benefits and long term contribution towards TQM, International Journal of Quality \& Reliability Management, 19, pp. 151-169.

[18] Graziano, A.M. \& Raulin, M.L. 1993. Research methods: A process of inquiry. HarperCollins College Publishers. New York

[19] Rolfe, G. 2006. Validity, trustworthiness and rigour: Quality and the idea of qualitative research, Journal of Advanced Nursing, 53, pp. 304-310.

[20] Casadesús, M. \& Karapetrovic, S. 2005. Has ISO 9000 lost some of its lustre? A longitudinal impact study, International Journal of Operations \& Production Management, 25, pp. 580-596.

[21] Casadesús, M. \& Gimenez, G. 2000. The benefits of the implementation of the ISO 9000 standard: Empirical research in 288 Spanish companies, The TQM Magazine, 12, pp. 432-441.

[22] Sun, H. 1999. Diffusion and contribution of total quality management: An empirical study in Norway, Total Quality Management, 10, pp. 901-914.

[23] Meyers, D.C., Durlak, J.A. \& Wandersman, A. 2012. The quality implementation framework: A synthesis of critical steps in the implementation process, American Journal of Community Psychology,. 50, pp. 462480.

[24] Daleiden, E.L. \& Chorpita, B.F. 2005. From data to wisdom: Quality improvement strategies supporting large-scale implementation of evidence-based services, Child and Adolescent Psychiatric Clinics, 14, pp. 329-349.

[25] Martínez Fuentes, C., Balbastre Benavent, F., Angeles Escribá Moreno, M., González Cruz, T. \& Pardo del Val, M. 2000. Analysis of the implementation of ISO 9000 quality assurance systems, Work Study, 49, pp. 229-241.

[26] Martinez Costa, M. \& Martinez Lorente, A.R. 2007. ISO 9000: 2000: The key to quality? An exploratory study, Quality Management Journal, 14, pp. 7-18.

[27] Kamieniecki, S., Shafie, D. \& Silvers, J. 1999. Forming partnerships in environmental policy: The business of emissions trading in clean air management, American Behavioral Scientist, 43, pp. 107-123.

[28] Williams, J.A. 2004. The impact of motivating factors on implementation of ISO 9001: 2000 registration process, Management Research News, 27, pp. 74-84.

[29] Neely, A., Gregory, M. \& Platts, K. 1995. Performance measurement system design: A literature review and research agenda, International Journal of Operations \& Production Management, 15, pp. 80-116. 
[30] Magd, H. \& Curry, A. 2003. An empirical analysis of management attitudes towards ISO $9001: 2000$ in Egypt, The TQM Magazine, 15, pp. 381-390.

[31] Sadgrove, K. 1994. ISO 9000 BS5750 made easy: A practical guide to quality. Kogan Page. United Kingdom

[32] Leung, H.K., Chan, K.C. \& Lee, T. 1999. Costs and benefits of ISO 9000 series: A practical study, International Journal of Quality \& Reliability Management, 16, pp. 675-691.

[33] Yeung, A., Lee, T. \& Chan, L. 2003. Senior management perspectives and ISO 9000 effectiveness: An empirical research, International Journal of Production Research, 41, pp. 545-569.

[34] Arumugam, V., Ooi, K.-B. \& Fong, T.-C. 2008. TQM practices and quality management performance: An investigation of their relationship using data from ISO 9001: 2000 firms in Malaysia, The TQM Journal, 20, pp. 636-650. 